\title{
Recycled Aggregate Self-Curing Concrete under Elevated Temperatures
}

\author{
Alaa A. Bashandy ${ }^{1}$, Noha M. Soliman1, Mohamed I. Nemr ${ }^{2}$ \\ ${ }^{1}$ Civil Eng. Dep., Faculty of Eng., Menoufia University, Egypt. \\ ${ }^{2}$ Civil Engineer, M. Sc. Candidate.
}

\begin{abstract}
Self-curing concrete is one of the important new types of concrete due to the scarcity of water especially, in the desert areas. Recycling waste demolitions as coarse aggregates for concrete is one of the recent solutions to reduce its bad impact on the environment. In this research, the both types will be combined. This research aims to investigate the behavior of recycled aggregate self-curing concrete under elevated temperatures. The main variables are; aggregate types (recycled vs. natural), elevated temperatures $\left(200^{\circ} \mathrm{C}, 400^{\circ} \mathrm{C}\right.$, and $600^{\circ} \mathrm{C}$ ), cooling methods (in the air or by using water), and storage time after cooling (for 1 or 28 days). Results are driven in terms of compressive, splitting tensile, flexure, and bond strengths. Test results showed that the recycled aggregate self-curing concrete could be used under elevated temperature considering a strength loss. The use of self-curing and recycled aggregate self-curing concrete may be considered as an alternative solution to the use of conventional curing concrete for infrastructures. Using crushed ceramics as a coarse aggregate at elevated temperature is efficient. The use of recycled aggregate self-curing concrete may consider as an alternative solution to the use of conventionally cured concrete in infrastructures. Firefighting is not recommended by using water due to its bad effects after cooling.
\end{abstract}

Keywords: Self-curing concrete; Recycled aggregate; Elevated temperature; Cooling, Storage time.

\section{Introduction}

There are two cases of fire effects on concrete. Direct fire and indirect fire effects, which considered as elevated temperatures. Fire or elevated temperatures affect badly on most types of concrete, especially when the concrete strength increased [1]. Several researchers have studied normal strength concrete (NSC) subjected to fire or elevated temperatures under the effect of varying aggregate types, high temperature, heating rate, cooling rate, and storage time after the test $[2,3,4$, 5]. Increasing heating time and heating temperature decreases the residual concrete strength for most types of concretes [3, 4, 6]. Cooling system and storing time after heating are important factors affecting strength loss of concrete despite its type $[5,4]$. During heating samples, the strength of concrete decreases with a range of $15-40 \%$, 55$70 \%$ for temperatures of $300^{\circ} \mathrm{C}$ and $550^{\circ} \mathrm{C}$, respectively of its original value $[2,7]$. The range between $400^{\circ} \mathrm{C}$ and $800^{\circ} \mathrm{C}$ is critical to the strength loss [8]. At a temperature of over $600^{\circ} \mathrm{C}$, common concretes suffered deterioration and only a small part of the initial strength is left, ranging from $7 \%$ to $25 \%$ [9]. The temperature exposure exceeds $700^{\circ} \mathrm{C}$ is not recommended for conventional concrete [10]. The surface cracks become visible when the temperature reaches $600^{\circ} \mathrm{C}$. The cracks are very pronounced at $800^{\circ} \mathrm{C}$ and increase extremely when the temperature is increased to $1000^{\circ} \mathrm{C}$ [11]. Previous experiments on concrete under high temperatures have mainly concentrated on the reduction of stiffness and strength properties. Only a few studies are concerned with the combined effect of high temperature and heating time on the residual strength of concrete [3, $12]$.

Curing of concrete can be performed externally by adding water or by preventing internal water to be evaporated. Also, internal curing "IC" which is curing concrete without using any external water or external curing can be conducted by using two techniques, permeable aggregates (which acts as internal reservoirs such as wood powder, lightweight aggregates such as lightweight sand "LWS" or lightweight aggregates "LWA" or by using chemical curing agents such as chemical additives (super-absorbent polymers "SAP" and shrinkage reducing admixture "SRA") [13]. Selfcuring (SC) concrete is a type of concrete, which did not need conventional curing after molding concrete that is based on the technique [14].

It behaves well under elevated temperatures with acceptable durability [4, 15]. The compressive 


\section{Alaa A. Bashandy, Noha M. Soliman, Mohamed I. Nemr, "Recycled Aggregate Self-Curing Concrete Under Elevated Temperatures"}

strength will be enhanced by the reduced shrinkage rising from water evaporation, making it ideal for concrete placing without any external curing [16, 17].

To reduce the risk of cracking in concrete caused by drying shrinkage, using SRA is recommended $[18,19]$. The risk of cracking related to drying shrinkage can be mitigated but not eliminated by using SRA to reduce the shrinkage [20]. Using polyethylene glycol 400, "PEG 400" is more effective than most valid curing compounds to obtain SC concrete [21]. It acts as a chemical curing agent to reduce water evaporation by increasing its viscosity.

In recent years, using waste construction materials become an essential need to reduce their bad impact on the environment. Several researchers suggest using it as coarse aggregates for concrete $[22,23,24,25,26,27,28]$. Concrete casts using recycled aggregates (RA) as coarse aggregate is less suitable for structural concrete.

The compressive strength of recycled aggregate concrete "RAC" is lower than that of conventional concrete, but when using recycled aggregate with self-curing concrete "SC-RA" the obtained strength is comparable to conventional concrete cast using recycled aggregates $[29,28]$. Using dolomite as a concrete coarse aggregate with self-curing concrete is more efficient than using recycled aggregates such as crushed concrete or crushed bricks with self-curing concrete [28].

When considering the SC at elevated temperature, the reduction of the strength of SC is dependent on target temperature, heating time, and cooling method. Increasing temperature and time led to a decrease in the strength of SC samples [4]. Left samples in the air are better than cooling using water [4]. Using recycled coarse aggregate with SC concrete mixes affecting in decreasing compressive, splitting tensile, and flexural strengths, compared to that using dolomite as a natural aggregate [30]. The residual compressive strength decreases as increasing the elevated temperatures $[3,4]$.

In this research, the behavior of self-curing concrete cast using recycled aggregates to obtain recycled aggregate self-curing "RA-SC" concrete is studied. In addition, the performance of this concrete type under the effect of indirect fire effects (elevated temperatures) compared to using dolomite as natural coarse aggregate studied.

\section{Research Significance}

This study aims to investigate the effects of elevated temperature, cooling methods, and storage time after exposure to elevated temperatures on recycled aggregate self-curing "RA-SC" concrete compared to self-curing "SC" concrete. The importance of this work is based on the need to know the data available addressing the behavior of RA-SC under the effect of elevated temperature. This study provides data concerning the main mechanical properties of RA-SC under high temperatures. The innovations in this research are the use of different recycled coarse aggregates with self-curing concrete to obtain applicable RA-SC concrete. Also, the effect of elevated temperature on RA-SC concrete considering the cooling methods and storage times.

\section{Experimental Program}

The experimental program is shown in Fig. (1). All tests in this study are carried out in the Construction Materials Laboratory in the Civil Engineering Department, Faculty of Engineering, Menoufia University.

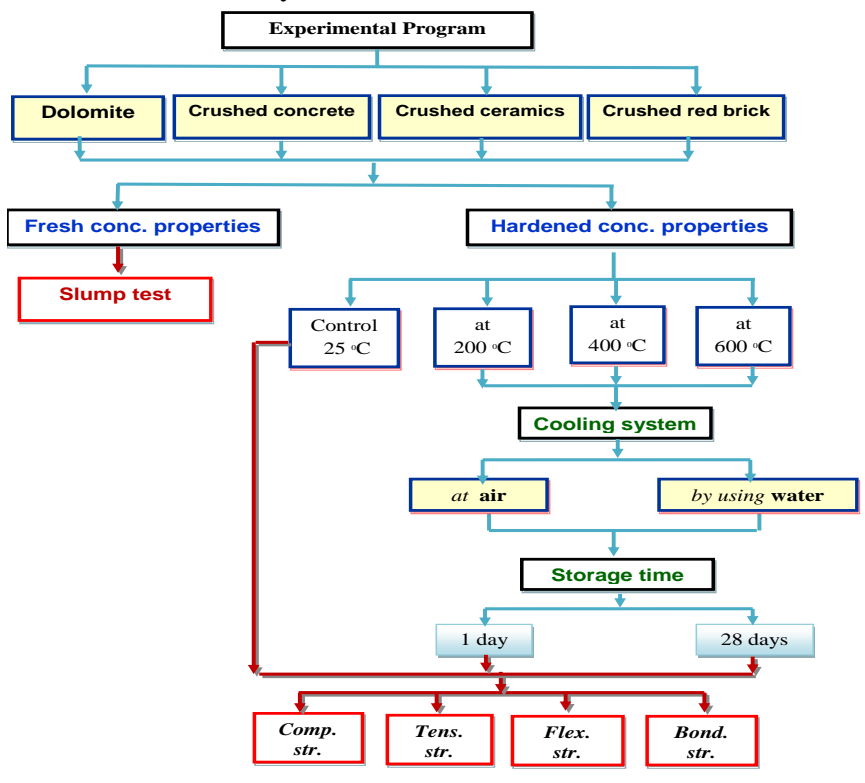

Fig. 1: The flow chart of the experimental program.

\subsection{Materials}

The cement used was the ordinary Portland cement CEM I $42.5 \mathrm{~N}$. It obtained from the Lafarge Cement Factory. It satisfies the Egyptian Standard specification (E.S.S. 4756-1/2013) [31] and its properties are given in Table (1). 
https://erjm.journals.ekb.eg

ISSN: 1110-1180

DOI:

Table 1: Main properties of the cement used

\begin{tabular}{|c|c|c|}
\hline Test Description & $\begin{array}{c}\text { Test } \\
\text { Results }\end{array}$ & $\begin{array}{l}\text { E.S.S. 4756- } \\
1 / 2013 \\
\text { Specification } \\
\quad \text { Limits } \\
\end{array}$ \\
\hline Specific gravity & 3.15 & 3.15 \\
\hline $\begin{array}{l}\text { Water percentage for the standard } \\
\text { consistency } \mathrm{w} / \mathrm{c} \% \text { of paste. }\end{array}$ & $27 \%$ & $25-30$ \\
\hline $\begin{aligned} \text { Setting time } & (\text { Vicat test): } \\
& \quad \text { Initial } \\
& \bullet \text { Final }\end{aligned}$ & $\begin{array}{l}\mathrm{hr}: \\
\min \\
1: 20 \\
5: 30\end{array}$ & $\begin{array}{l}\text { Not less than } \\
45 \text { min. } \\
\text { Not more } \\
\text { than } 10 \mathrm{hr} \text {. }\end{array}$ \\
\hline $\begin{array}{l}\text { The fineness of hydraulic cement ( } \\
\text { sieve No. 170) }\end{array}$ & $7 \%$ & $\begin{array}{l}\text { Not more } \\
\text { than } 10 \%\end{array}$ \\
\hline $\begin{array}{l}\text { Compressive Strength: } \\
2 \text { days } \\
28 \text { days }\end{array}$ & $\begin{array}{l}10 \\
42\end{array}$ & $\begin{array}{c}8(\mathrm{MPa}) \\
40(\mathrm{MPa})\end{array}$ \\
\hline $\begin{array}{l}\text { Sandiness expansion } \\
\text { (le-chatalies test) (mm) }\end{array}$ & 1 & $\begin{array}{l}\text { Not more } \\
\text { than } 10 \mathrm{~mm}\end{array}$ \\
\hline
\end{tabular}

The fine aggregate used was the natural siliceous clean and nearly free from impurities sand with a specific gravity $2.6 \mathrm{t} / \mathrm{m}^{3}$ and a fineness modulus 2.52 that satisfies the (E.S.S 1109/2008) [32]. Its grading is given in Table (2) while its mechanical properties are given in Table (3). Two types of coarse aggregates were used natural and recycled aggregates. The dolomite as a natural aggregate and three types of recycled aggregates (crushed concrete, crushed ceramics, and crushed red bricks) were used. Recycled coarse aggregates with a $100 \%$ replacement ratio of dolomite having a maximum nominal size of $20 \mathrm{~mm}$ were used. Physical and mechanical properties of coarse aggregate used are given in Tables (4) satisfies the (E.S.S 1109/2008) and (ASTM C-33) [32, 33]. The shape of those particles is irregular and angular with a very low percentage of flat particles. Water used was drinkable clean water, fresh and free from impurities. It was used for mixing the concrete of tested samples according to the Egyptian Code of Practice (E.C.P. 203/2018) [34].

Table 2: Grading of fine aggregate according to (ASTM C33)

\begin{tabular}{ccc}
\hline $\begin{array}{c}\text { Sieve Size } \\
(\mathrm{mm})\end{array}$ & $\begin{array}{c}\text { \% Passing of } \\
\text { sand used }\end{array}$ & $\begin{array}{c}\text { \% Passing } \\
(A S T M C 33)\end{array}$ \\
\hline 9.5 & $\mathbf{1 0 0}$ & 100 \\
\hline 4.75 & $\mathbf{1 0 0}$ & $100-95$ \\
\hline 2.36 & $\mathbf{9 4}$ & $100-80$ \\
\hline 1.18 & $\mathbf{8 0}$ & $85-50$ \\
\hline 0.61 & $\mathbf{5 0}$ & $60-25$ \\
\hline 0.31 & $\mathbf{1 5}$ & $30-5$ \\
\hline 0.16 & $\mathbf{0}$ & $10-0$ \\
\hline
\end{tabular}

\section{Engineering Research Journal Faculty of Engineering Menoufia University}

Table 3: Physical and mechanical properties of sand used

\begin{tabular}{lcc}
\hline \multicolumn{1}{c}{ Description } & & Value \\
\hline Volume weight & $\left(t / \mathrm{m}^{3}\right)$ & 1.73 \\
Specific gravity & & 2.6 \\
$\%$ absorption & $(\%)$ & 0.78 \\
Void ratio & $(\%)$ & 33.81 \\
Fineness modulus & & 2.61 \\
\hline
\end{tabular}

Table 4: Physical properties of the coarse aggregates used

\begin{tabular}{ccccc}
\hline Property & D & CC & CY & CRB \\
\hline $\begin{array}{c}\text { Specific gravity } \\
\left(\mathrm{Kg} / \mathrm{cm}^{3}\right)\end{array}$ & 2.6 & 2.4 & 2.3 & 1.6 \\
\hline Absorption $(\%)$ & 0.6 & 3 & 6.4 & 11.4 \\
\hline $\begin{array}{c}\text { Aggregate } \\
\text { crushing value } \\
(\text { ACV) }(\%)\end{array}$ & 16.6 & 24.9 & 16.8 & 50.5 \\
\hline $\begin{array}{c}D=\text { Dolomite, CC= Crushed Concrete, } \\
C C=\text { Crushed Ceramics, } C R B=\text { Crushed Red Bricks }\end{array}$
\end{tabular}

Two chemical admixtures were used. The first is a high-range water-reducing admixture (HRWRA). It was often referred to as super-plasticizers that help in increasing the workability of concrete without the additional amount of water. A naphthalene sulphonate group-based super-plasticizer, supplied by Chemicals for Modern Buildings Company (CMB) under the brand name of Addicrete BVF was chosen to be used in this study. Its base is Naphthalene sulphonate, in a liquid state with a Brown color. Its density is $1.18 \pm 0.01 \mathrm{~kg} / \mathrm{lit}$ with a nil amount of chloride content and air entrainment (As provided by the manufacturer). The used super-plasticizer complies with (ASTM C494-Type F) [35]. The second is a self-curing chemical agent. In this study, polyethylene glycol "PEG 400" in a liquid form for internal curing of concrete was used. It is free from chlorides and produces an internal membrane, which protects and prevents fresh concrete from over-rapid water evaporation. Its average molecular weight is 380-420. Hydroxyl Number is 264 to $300 \mathrm{Mg} \mathrm{KOH} / \mathrm{g}$. Melting or Freezing range is $4-8^{\circ} \mathrm{C}$. It is complete soluble in water at $20^{\circ} \mathrm{C} \%$. Its viscosity at $100^{\circ} \mathrm{C}$ is equal to 7.3 . Its Liquid Density is $1.1255,1.0931$ and $1.0769 \mathrm{~g} / \mathrm{cc}$ at temperatures of $20^{\circ} \mathrm{C}, 60^{\circ} \mathrm{C}$ and $80^{\circ} \mathrm{C}$, respectively $(A s$ provided by the manufacturer). The agent was obtained from Morgan Chemicals Pvt. Ltd, Egypt. 


\section{Alaa A. Bashandy, Noha M. Soliman, Mohamed I. Nemr, "Recycled Aggregate Self-Curing Concrete Under Elevated Temperatures"}

\subsection{Concrete and Tested Samples}

The concrete mixes are shown in Table (5). The mix proportions were chosen based on previous research conducted by Bashandy et al., 2016 [28]. The concrete was evaluated in terms of a slump test (as a fresh concrete property) and terms of compressive, splitting tensile, flexure, and bond strengths (as hardened concrete properties). Samples were cast using concrete mixtures then stored at room temperature $\left(25^{\circ} \mathrm{C}\right)$ and relative humidity of approximately $72 \%$ for 28 days. A total number of 156 samples were cast for each test. For each test, three samples were used then their average is obtained. Cubes $(100 \times 100 \times 100 \mathrm{~mm})$ were used to evaluate compressive strength, cylinders $(100 \times 200 \mathrm{~mm})$ were used to obtain splitting tensile strength, prisms $(100 \times 100 \times 500 \mathrm{~mm})$ were used to obtain flexure strength, and cubes $(150 \times 150 \times 150 \mathrm{~mm})$ with embedded rebars of $10 \mathrm{~mm}$ diameter and $160 \mathrm{~mm}$ height were used to have bond strength.

Table 5: Concrete mixes used

\begin{tabular}{|c|c|c|c|c|}
\hline $\begin{array}{l}\text { Type of coarse } \\
\text { aggregate }\end{array}$ & D & $\mathrm{CC}$ & $\mathbf{C Y}$ & CRB \\
\hline Mix. & MD & $\mathrm{MC}$ & MY & MB \\
\hline Cement $\left(\mathrm{kg} / \mathrm{m}^{3}\right)$ & \multicolumn{4}{|c|}{350} \\
\hline $\mathbf{W} / \mathbf{C}^{*}$ & \multicolumn{4}{|c|}{0.5} \\
\hline Sand $\left(\mathrm{kg} / \mathrm{m}^{3}\right)$ & 614.8 & 598.8 & 565.6 & 433.9 \\
\hline $\begin{array}{l}\text { Corse } \\
\text { aggregate } \\
\left(\mathrm{kg} / \mathrm{m}^{3}\right)\end{array}$ & 1229.6 & 1197.6 & 1131.2 & 867.9 \\
\hline $\begin{array}{l}\text { Super- } \\
\text { plasticizer } \\
\left(\mathrm{kg} / \mathrm{m}^{3}\right)\end{array}$ & \multicolumn{4}{|c|}{3.5} \\
\hline $\begin{array}{l}\text { Chemical agent } \\
\text { PEG400 } \\
\left(\mathrm{kg} / \mathrm{m}^{3}\right)\end{array}$ & \multicolumn{4}{|c|}{1.75} \\
\hline $\begin{array}{l}\text { F }_{\mathrm{cu}} \mathbf{2 8} \text { days } \\
(M P a)\end{array}$ & 24 & 18.5 & 26.8 & 11.8 \\
\hline Slump $(\mathrm{mm})$ & 225 & 215 & 230 & 205 \\
\hline
\end{tabular}

\subsection{Testing Methodology and Elevated}

\section{Temperatures}

The experimental program was divided into two stages. The first stage was conducted to obtain the main properties of recycled aggregates self-curing RA$\mathrm{SC}$ concrete. The second stage was conducted to study the effect of exposure to elevated temperatures (200 ${ }^{\circ} \mathrm{C}, 400{ }^{\circ} \mathrm{C}$, and $600{ }^{\circ} \mathrm{C}$ measured at the core of each sample by using thermo-cables) then left at that temperature for 1 hour. After that, the samples were cold down by using one of two methods (left in the air or immersed in water at $25^{\circ} \mathrm{C}$ ). To cooling in air, the samples were cooled at laboratory temperature at $25{ }^{\circ} \mathrm{C}$ as a slow cooling method while cooling by using water; samples are immersed in the water at $25^{\circ} \mathrm{C}$ as a fast cooling method. The samples were stored in a laboratory atmosphere after exposure to elevated temperatures for 1 or 28 days as storage time, and then tested to judge the RA-SC concrete characteristics.

\section{Test Results}

The results obtained from the performed tests on selfcuring concrete cast using recycled aggregates under the effect of elevated temperature are discussed in this section in terms of; the effects of aggregate type, temperature degree, cooling method and storage time.

\subsection{Effects of Coarse Aggregate Type on RA-SC Concrete}

After casting the concrete samples, they left in laboratory temperature for 28 days, then tested as a control sample to get their main mechanical properties (compressive, splitting tensile, flexure, and bond strengths). The obtained results are shown in Figs. (2) to (5).

All test results were compared to samples cast using dolomite (as a natural aggregate) at the same temperature. The values of compressive, splitting tensile, flexure, and bond strengths were decreased when using RA. As using crushed concrete, crushed ceramics, and crushed red bricks the strengths decrease by a range of 15.4-36.5\%, 4.3-16.1\%, and 33.3$55.6 \%$, respectively compared to those cast employing dolomite as coarse aggregate. Using crushed ceramics as a recycled coarse aggregate with self-curing concrete is more efficient compared to other types of recycled aggregates used. That may because of its small crushing factor compared to other recycled aggregates used, which led to a higher strength. Based on the obtained results, recycled aggregates concrete "RAC" is less suitable for structural concrete compared to natural aggregate but it may be considered when casting nonstructural concrete as an economic alternative.

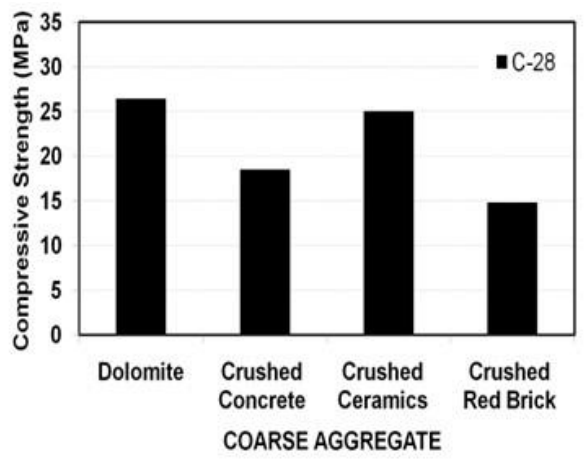




\section{Alaa A. Bashandy, Noha M. Soliman, Mohamed I. Nemr, "Recycled Aggregate Self-Curing Concrete Under Elevated Temperatures"}

Fig. 2: Compressive strength values of self-curing concretes with different types of recycled coarse aggregates compared to that cast using dolomite after

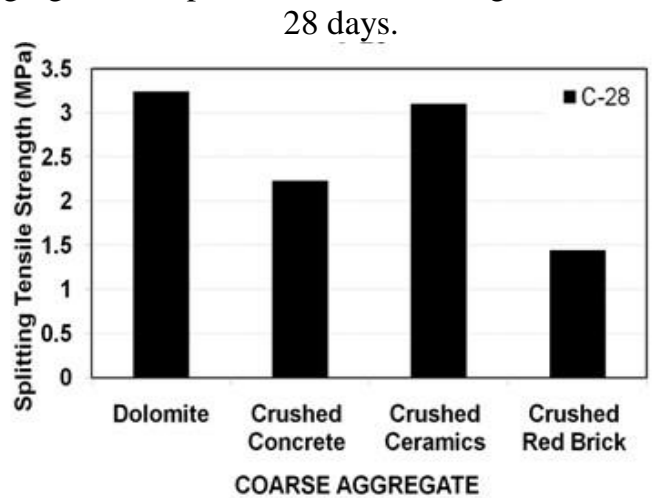

Fig. 3: Splitting tensile strength values of self-curing concretes with different types of recycled coarse aggregates compared to that cast using dolomite after

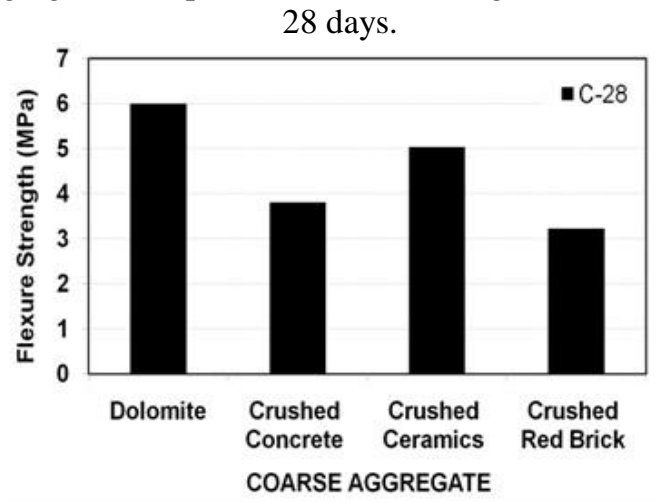

Fig. 4: Flexural strength values of self-curing concretes with different types of recycled coarse aggregates compared to that cast using dolomite after 28 days.

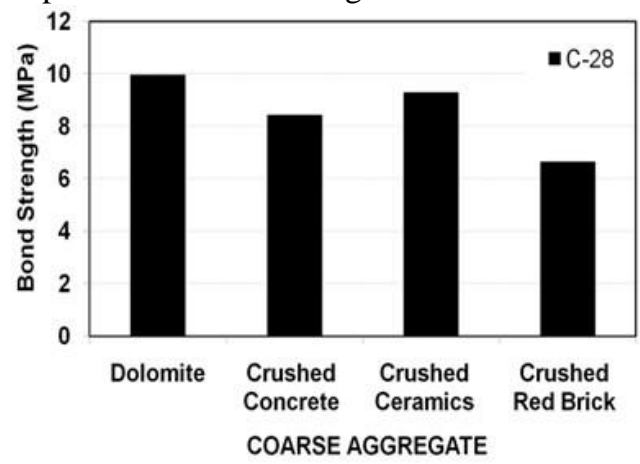

Fig.5: Bond strength values of self-curing concretes with different types of recycled coarse aggregates compared to that cast using dolomite after 28 days.

\subsection{Effects of Elevated Temperature on RA-SC Concrete}

The residual strength of RA-SC concrete is affected mainly by the target temperature and cooling method as show in Figs. (6) to (21).
When considering the cooling at air, after exposing to $200^{\circ} \mathrm{C}$ then cooled at air, then stored for 1 day, the strength values decrease when cast using crushed concrete, crushed ceramics, and crushed red bricks by a range of $17.8-37.8 \%, 5-13.5 \%$, and 32.5-60.3\%, respectively compared to those cast using dolomite as a coarse aggregate. As increasing the storage time to 28 days after cooling, the strengths of the RA-SC concrete cast using crushed concrete, crushed ceramics, and crushed red bricks decreased by a range of 17.8-38.4\%, 2.9-13.7\%, and 32.6-60.3\%, respectively compared to that cast using dolomite. That may refer to their crushing factor and the weak of crushed red bricks compared to other types used.

After exposing to $400{ }^{\circ} \mathrm{C}$ then cooled at the air then stored for 1 day, the strength values decreased when cast using crushed concrete, crushed ceramics, and crushed red bricks by a range of 24.9-39.2 \%, 4.5$13.9 \%$, and $36-53.2 \%$, respectively compared to those cast using dolomite as a coarse aggregate. As increasing the storage time to 28 days, the strengths of the RA-SC concrete cast using crushed concrete, crushed ceramics, and crushed red bricks decreased by a range of 25.6-37.2 \%, 0.4-12.9\%, and 35.6-53.6\%, respectively compared to that cast using dolomite. That may refer to their crushing factor and the presence of voids.

After exposing to $600{ }^{\circ} \mathrm{C}$ then cooled at the air, then stored for 1 day, the strength values decreased when cast using crushed concrete, crushed ceramics, and crushed red bricks by a range of 25.4-54.5\%, 4.2$27.3 \%$, and $42-57.6 \%$, respectively compared to that cast using dolomite as coarse aggregate. As increasing the storage time to 28 days, the strengths of the RA-SC concrete cast using crushed concrete, crushed ceramics, and crushed red bricks decreased by a range of 25.2$54.7 \%, 0.4-27.1 \%$, and 42.5-57.1 \%, respectively compared to that cast using dolomite. That may refer to the small crushing factor of crushed ceramics followed by crushed concrete used.

When considering the cooling by using water, after exposing to $200{ }^{\circ} \mathrm{C}$ then cooled by using the water then stored for 1 day, as using crushed concrete, crushed ceramics, and crushed red bricks the strength values decreased by a range of 31.2-47.8 \%, 2.3-14.2\%, and 36.5-55.9\%, respectively compared to that cast using dolomite as coarse aggregate. As increasing the storage time to 28 days, the strengths of the RA-SC concrete cast using crushed concrete, crushed ceramics, and crushed red bricks decreased by a range of 31.5$45.8 \%, 2-13.6 \%$, and $36.8-55.4 \%$ compared to that cast using dolomite as a coarse natural aggregate.

After exposing to $400{ }^{\circ} \mathrm{C}$ then cooled in the water then stored for 1 day, when using crushed concrete, crushed ceramics, and crushed red bricks the strength values decreased by a range of 27.7-37.5 \%, 3.9-14.8\%, and 


\section{Alaa A. Bashandy, Noha M. Soliman, Mohamed I. Nemr, "Recycled Aggregate Self-Curing Concrete Under Elevated Temperatures"}

35.7-52\%, respectively compared to that cast using dolomite as coarse aggregate. As increasing the storage time to 28 days after tests, the strengths of the RA-SC concrete cast using crushed concrete, crushed ceramics, and crushed red bricks decreased with ranges of $25.7-37 \%, 2.5-14.5 \%$, and 34.9-51.4\%, respectively compared to that cast using dolomite.

After exposing to $600{ }^{\circ} \mathrm{C}$ then cooled in the water, then stored for 1 day, as using crushed concrete, crushed ceramics, and crushed red bricks the strength values were decreased with ranges of 23-57.6 \%, 4.4-40.3\%, and $40.5-59.4 \%$, respectively compared to that cast using dolomite as coarse aggregate. Therefore, increasing the storage time to 28 days, the strengths of the RA-SC concrete cast using crushed concrete, crushed ceramics, and crushed red bricks were decreased with ranges of 19.4-58 \%, 3-39.8\%, and 39.3-59\%, respectively compared to that cast using dolomite. This could be attributed to the effect of heat stability of ceramics due to its manufacturing compared to those of crushed concrete and crushed red bricks.

Comparison of the residual compressive strength test results, the residual splitting tensile strength, flexure, and bond strengths of RA-SC concrete. It is interesting to note that there is always drop continuously as the temperature is elevated as shown in Figs. (6) to (21). Concrete undergoes a significant change when exposed to high temperatures resulting in changing in structural properties. The residual strength decreases as increasing the exposure time to an elevated temperature in accordance with the previous researches for SC concrete and RA concrete [5, 4, 3, 36].

At the elevated temperatures used $\left(200{ }^{\circ} \mathrm{C}, 400{ }^{\circ} \mathrm{C}\right.$, and $600{ }^{\circ} \mathrm{C}$ ), cooling methods used (air or water cooling methods) and storage time 1 day or 28 days after testing) all results decrease compared to the results of the control sample. Strength results (compressive, splitting tensile, flexure and bond strengths) decreased for each recycled coarse aggregate type used in this study by a range of $1.4-69.4 \%$ as shown in Table (5). The results are comparable to those for SC concrete obtained by Bashandy, $2015[4,10]$.

\subsection{Effects of Storage Time after Exposing to Elevated Temperatures}

The effects of storage time (for 1 or 28 days after exposure to elevated temperatures) on RA-SC concrete are shown in Figs. (6) to (21). The decrease in the strength of SC and RA-SC concretes increases with the rising of temperature.

For samples cooled in the air then tested after 28 days, all strength results (compressive, splitting tensile, flexure, and bond strength) decrease for all coarse aggregate types compared to the same obtained results when tested after a storage time of 1 day at each elevated temperature (at 200, 400 and $600{ }^{\circ} \mathrm{C}$ ) by a range of $1.1-10.5 \%$ as showed in Table (7).

For samples cooled by using water then tested after a storage time of 28 days, all strength results increased compared to the same samples tested after a storage time of 1 day at each elevated temperature with a range of 0.6-7.5 \% as showed in Table (6). This may be referred to the re-arrangement of the internal stresses in the concrete during the storage time of 28 days.

Increasing the storage time for RA-SC concrete after cooling in the air increases their residual strengths.

\subsection{Effect of Cooling Methods on RA-SC Concrete} The effects of cooling RA-SC concrete after exposure to elevated temperatures were compared to those samples cooling in the air as a slow cooling method are shown in Figs. (6) to (21). The values of compressive, splitting tensile, flexure, and bond strengths decreased for each change in coarse aggregate type.

After exposing to $200{ }^{\circ} \mathrm{C}$ then cooled in water then stored for 1 day, when cast using dolomite, crushed concrete, crushed ceramics, and crushed red bricks the strengths were decreased with ranges of 10.7-32\%, $17.1-34 \%, 17.6-27.8 \%$, and $12.9-30.3 \%$, respectively compared to those of the samples cooled in air such as slow cooling method. As increasing the storage time to 28 days, the strengths of the concrete cast using dolomite, crushed concrete, crushed ceramics, and crushed red bricks were decreased with ranges of 7.2$29.3 \%, 13.2-29.6 \%, 14.2-25.5 \%$, and 7.5-26.1\%, respectively.

After exposing to $400{ }^{\circ} \mathrm{C}$ then cooled in water then stored for 1 day, as cast using dolomite, crushed concrete, crushed ceramics, and crushed red bricks the strengths were decreased with ranges of 15.8-49.3\%, 13.4-43.3\%, 12.8-47.9\%, 15-45\%, respectively compared to those samples cooled in air. As increasing the storage time to 28 days, the strengths of the concrete cast using dolomite, crushed concrete, crushed ceramics, and crushed red bricks were decreased with ranges of 5.3-46.3\%, 9.5-38.7 \%, 9.1$41.8 \%$, and $7.8-38.7 \%$, respectively.

After exposing to $600{ }^{\circ} \mathrm{C}$ then cooled in water, then stored for 1 day, once cast using dolomite, crushed concrete, crushed ceramics, and crushed red bricks the strengths were decreased with ranges of 8.4-38.4\%, 14.5-35.5 \%, 24.8-38.5\%, 12.3-36.4\%, respectively compared to those samples cooled in air. As increasing the storage time to 28 days, the strengths of the concrete cast using dolomite, crushed concrete, crushed ceramics, and crushed red bricks decreased by a range of 1.8-31.9\%, 8.1-28.6\%, 18.9-33.6\%, and 6.1-28 \%, respectively compared to their original values. The lower decrease in crushed red bricks could be attributed to the presence of voids that afford a place to expand during elevated temperatures. 


\section{Alaa A. Bashandy, Noha M. Soliman, Mohamed I. Nemr, "Recycled Aggregate Self-Curing Concrete Under Elevated Temperatures"}

Air-cooling (as a slow cooling method) is more efficient compared to water-cooling (as a fast cooling method) after exposure to high temperatures. That may have been applied by using foam for firefighting instead of using water. Because using water cooling made a shock of concrete which causes cracking in the surface of samples. Results satisfy those obtained from self-curing concrete cast using natural aggregates at elevated temperatures [4, 36-39].

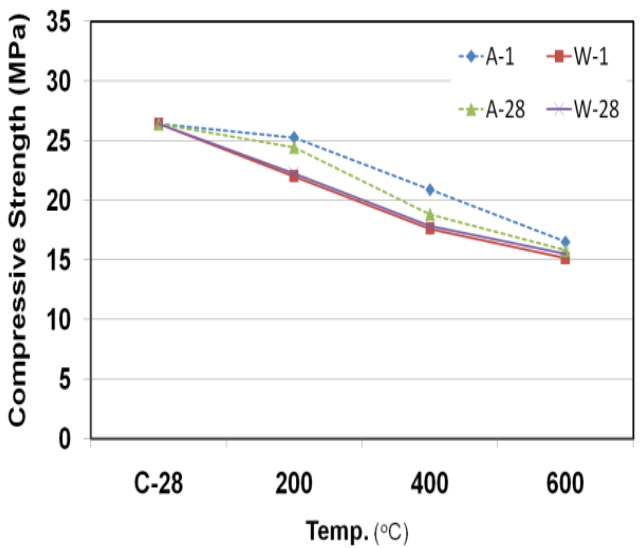

Fig. 6: Compressive strength values of the self-curing concrete cast using dolomite.

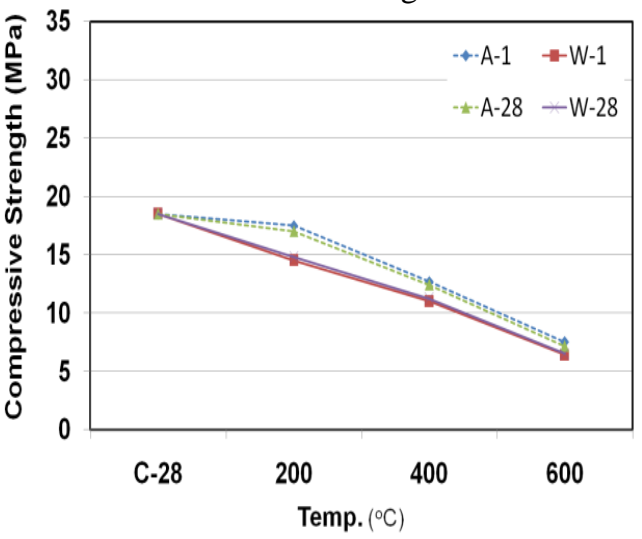

Fig. 7: Compressive strength values of the self-curing concrete cast using crushed concrete as recycled coarse aggregates.

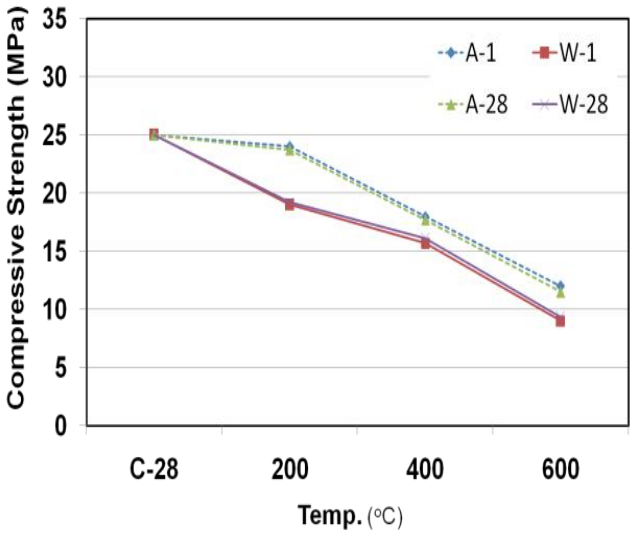

Fig. 8: Compressive strength values of the self-curing concrete cast using crushed ceramics as recycled

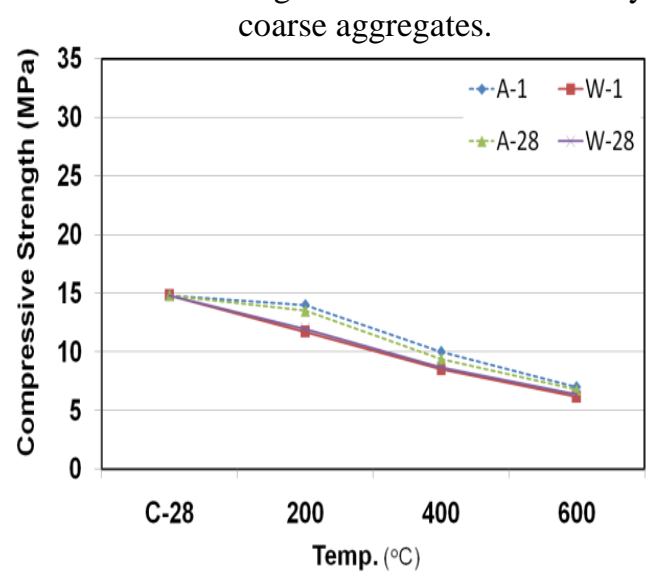

Fig. 9: Compressive strength values of the self-curing concrete cast using crushed red bricks as recycled coarse aggregates.

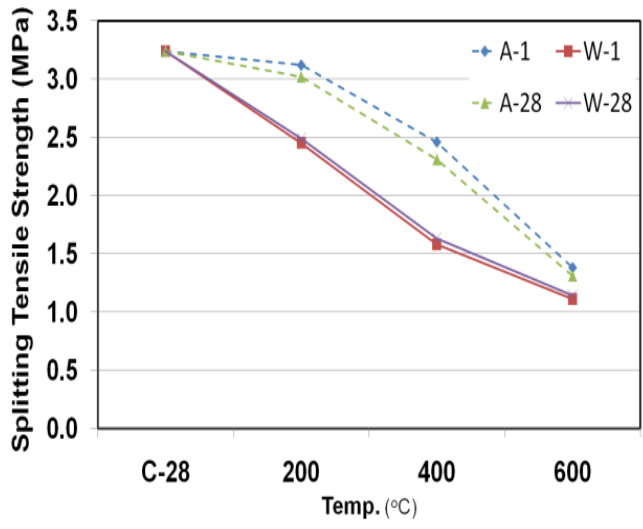

Fig. 10: Splitting tensile strength values of the selfcuring concrete cast using dolomite.

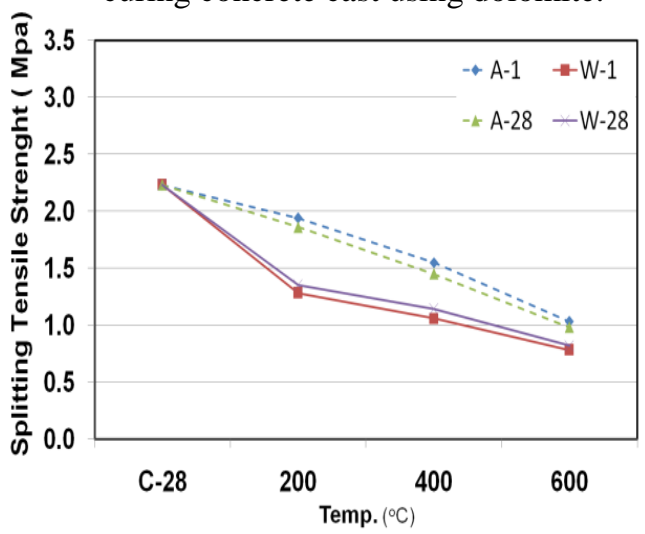

Fig. 11: Splitting tensile strength values of the selfcuring concrete cast using crushed concrete as recycled coarse aggregates. 


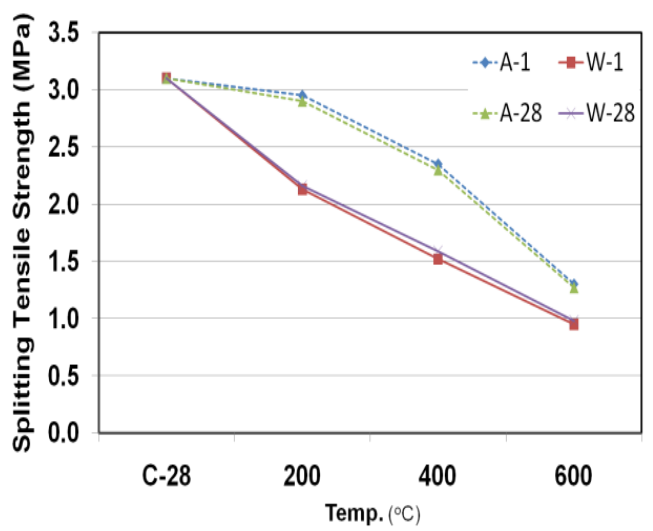

Fig. 12: Splitting tensile strength values of the selfcuring concrete cast using crushed ceramics as recycled coarse aggregates.

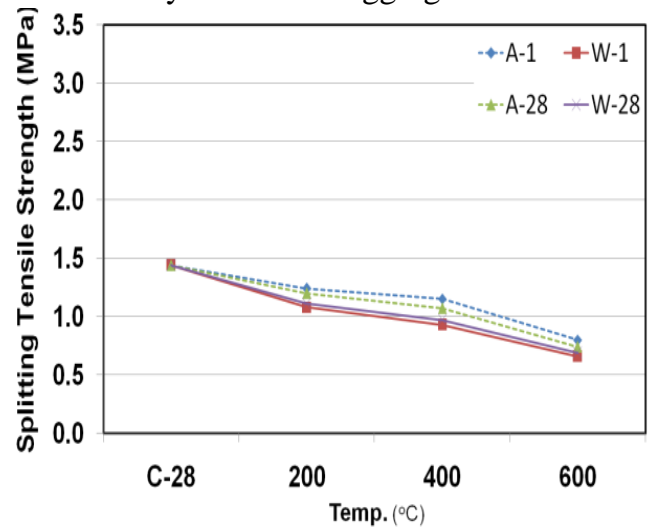

Fig. 13: Splitting tensile strength values of the selfcuring concrete cast using crushed red bricks as recycled coarse aggregates.

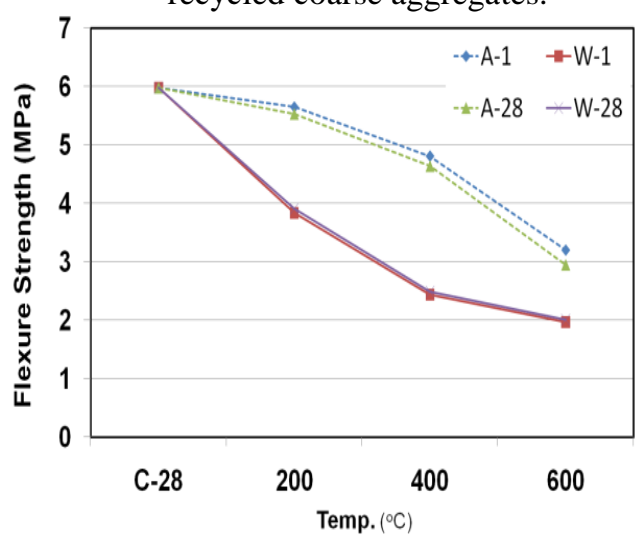

Fig. 14: Flexure strength values of the self-curing concrete cast using dolomite.

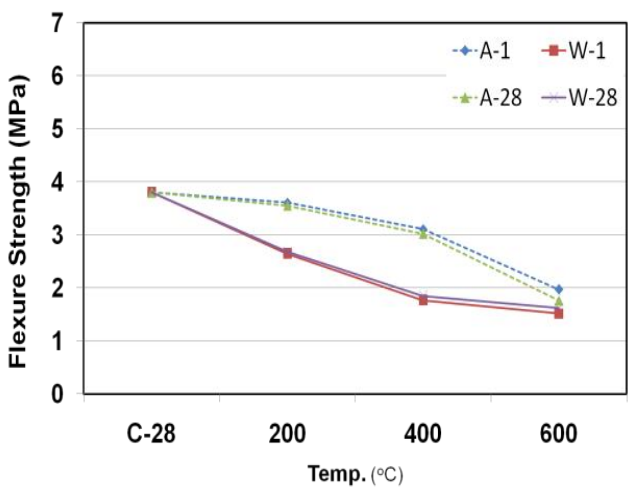

Fig. 15: Flexure strength values of the self-curing concrete cast using crushed concrete as recycled coarse aggregates.

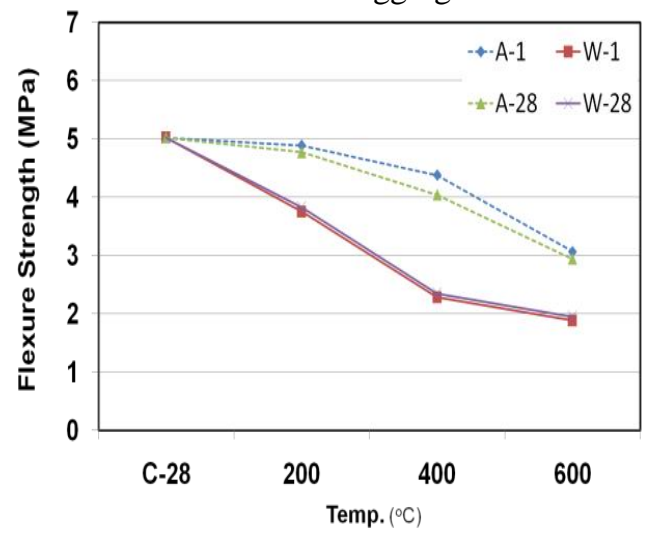

Fig. 16: Flexure strength values of the self-curing concrete cast using crushed ceramics as recycled

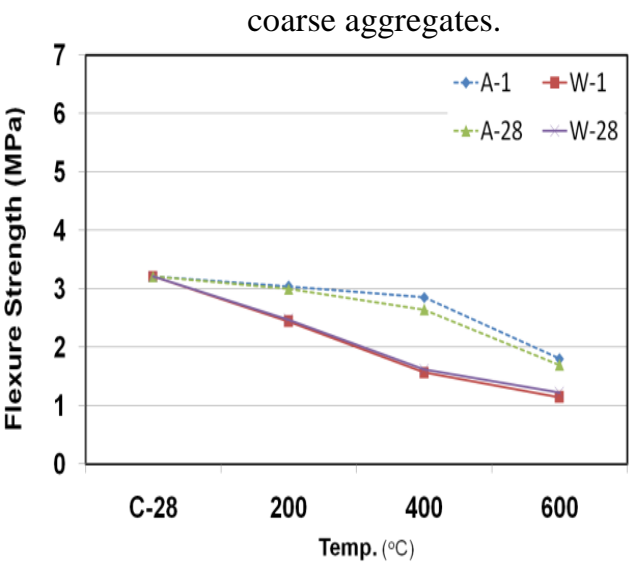

Fig. 17: Flexure strength values of the self-curing concrete cast using crushed red bricks as recycled coarse aggregates. 


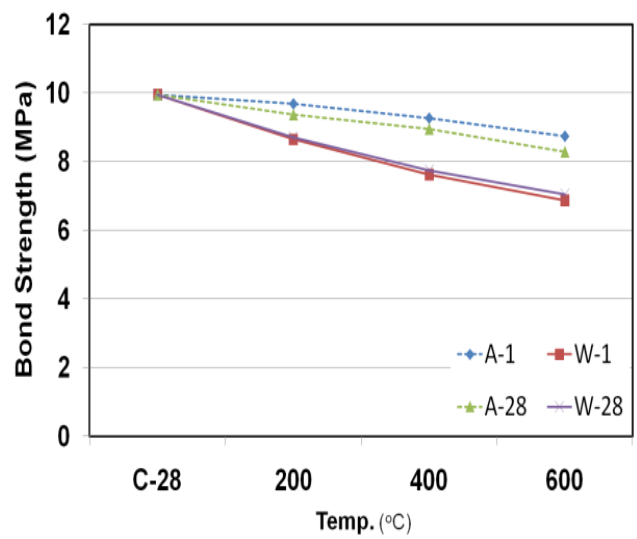

Fig. 18: Bond strength values of the self-curing concrete cast using dolomite.

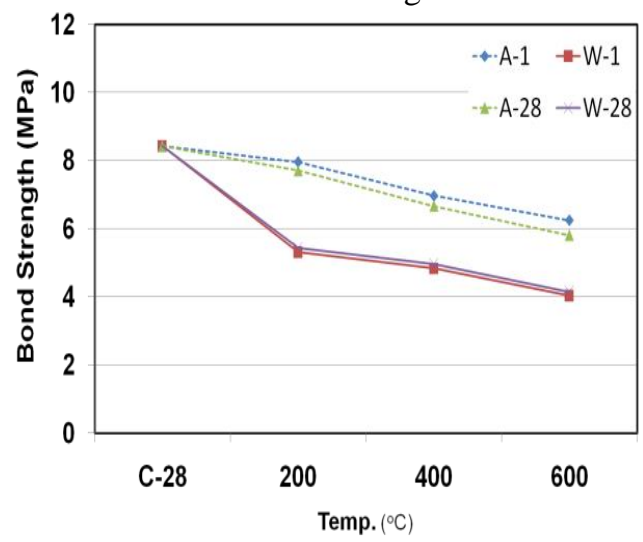

Fig. 19: Bond strength values of the self-curing concrete cast using crushed concrete as recycled coarse aggregates.

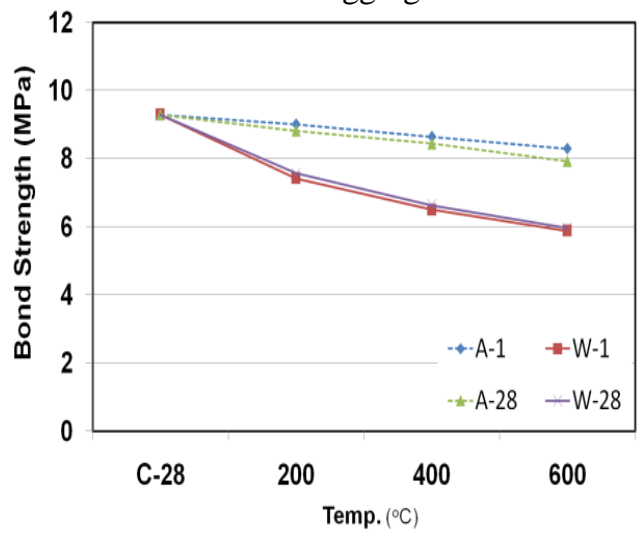

Fig. 20: Bond strength values of the self-curing concrete cast using crushed ceramics as recycled coarse aggregates.

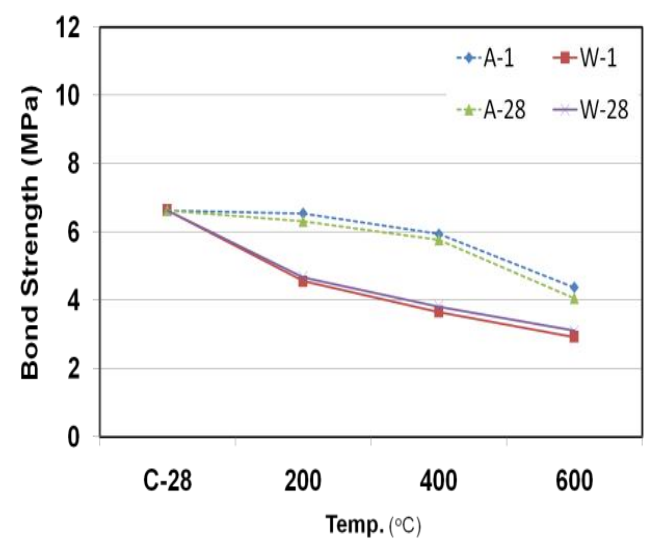

Fig. 21: Bond strength values of the self-curing concrete cast using crushed red bricks as recycled coarse aggregates 
Alaa A. Bashandy, Noha M. Soliman, Mohamed I. Nemr, "Recycled Aggregate Self-Curing Concrete Under Elevated Temperatures"

Table 6: The percentages of strength values after supposed to elevated temperatures compared to control samples.

\begin{tabular}{|c|c|c|c|c|c|c|c|c|c|c|c|c|c|c|}
\hline \multirow{2}{*}{ Strength } & \multirow{2}{*}{$\begin{array}{c}\text { COARSE } \\
\text { AGGREGATE }\end{array}$} & \multirow{2}{*}{$\frac{\text { Control }}{\text { C-28 }}$} & \multicolumn{2}{|c|}{$200 \mathrm{AIR}$} & \multicolumn{2}{|c|}{$400 \mathrm{AIR}$} & \multicolumn{2}{|c|}{600 AIR } & \multicolumn{2}{|c|}{200 WATER } & \multicolumn{2}{|c|}{400 WATER } & \multicolumn{2}{|c|}{600 WATER } \\
\hline & & & 200-A-1 & 200-A-28 & 400-A-1 & 400-A-28 & $600-\mathrm{A}-1$ & $600-\mathrm{A}-28$ & 200-W-1 & $200-W-28$ & $400-\mathrm{W}-1$ & $400-W-28$ & $600-\mathrm{W}-1$ & $600-\mathrm{W}-28$ \\
\hline \multirow{4}{*}{ 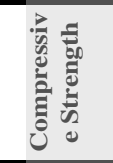 } & Dolomite & 0 & -4.3 & -7.4 & -20.8 & -28.7 & -37.5 & -40.2 & -16.7 & -15.7 & -33.3 & -32.4 & -42.7 & -41.3 \\
\hline & Crushed Concrete & 0 & -5.4 & -8.0 & -31.4 & -32.9 & -59.5 & -61.4 & -21.6 & -20.1 & -40.5 & -39.2 & -65.4 & -64.8 \\
\hline & Crushed Ceramics & 0 & -4.0 & -5.1 & -28.0 & -29.1 & -52.0 & -54.0 & -24.0 & -23.1 & -37.2 & -35.6 & -63.9 & -62.7 \\
\hline & Crushed Red Brick & 0 & -5.4 & -8.8 & -32.4 & -36.5 & -52.7 & -54.3 & -20.9 & -19.3 & -42.6 & -41.4 & -58.5 & -57.0 \\
\hline \multirow{4}{*}{ 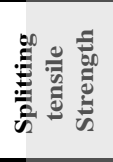 } & Dolomite & 0 & -3.7 & -6.8 & -24.1 & -28.7 & -57.4 & -59.6 & -24.4 & -23.1 & -51.2 & -49.7 & -65.7 & -64.8 \\
\hline & Crushed Concrete & 0 & -13.0 & -16.6 & -30.5 & -35.0 & -53.8 & -56.1 & -42.6 & -39.5 & -52.5 & -48.9 & -65.0 & -63.2 \\
\hline & Crushed Ceramics & 0 & -4.8 & -6.5 & -24.2 & -25.8 & -58.1 & -59.0 & -31.3 & -30.3 & -51.0 & -48.7 & -69.4 & -68.4 \\
\hline & Crushed Red Brick & 0 & -13.9 & -16.7 & -20.0 & -25.6 & -44.4 & -48.6 & -25.0 & -22.9 & -35.4 & -32.6 & -54.2 & -52.1 \\
\hline \multirow{4}{*}{ 造 } & Dolomite & 0 & -5.5 & -7.5 & -19.6 & -22.4 & -46.5 & -50.7 & -35.8 & -34.6 & -59.2 & -58.4 & -67.1 & -66.4 \\
\hline & Crushed Concrete & 0 & -5.0 & -6.6 & -18.2 & -20.5 & -48.2 & -53.6 & -30.4 & -29.5 & -53.6 & -51.3 & -60.1 & -57.4 \\
\hline & Crushed Ceramics & 0 & -2.6 & -5.0 & -12.7 & -19.5 & -38.9 & -41.5 & -25.3 & -23.7 & -54.6 & -53.2 & -62.5 & -61.2 \\
\hline & Crushed Red Brick & 0 & -5.3 & -6.7 & -11.1 & -17.7 & -44.0 & -47.2 & -24.0 & -23.1 & -51.1 & -49.6 & -64.3 & -62.0 \\
\hline \multirow{4}{*}{ हूँ } & Dolomite & 0 & -2.7 & -5.8 & -6.8 & -10.0 & -12.1 & -16.7 & -13.1 & -12.6 & -23.4 & -22.1 & -30.9 & -29.3 \\
\hline & Crushed Concrete & 0 & -5.4 & -8.4 & -17.2 & -20.8 & -25.8 & -31.0 & -37.0 & -35.5 & -42.5 & -41.1 & -52.1 & -50.7 \\
\hline & Crushed Ceramics & 0 & -3.0 & -5.0 & -7.0 & -9.2 & -10.7 & -14.6 & -20.1 & -18.5 & -30.0 & -28.6 & -36.8 & -35.8 \\
\hline & Crushed Red Brick & 0 & -1.4 & -4.7 & -10.5 & -13.0 & -34.1 & -38.8 & -31.3 & -29.6 & -44.8 & -42.5 & -56.0 & -53.1 \\
\hline
\end{tabular}

Table 7: The percentages of strength values after a storage time of 28-days compared to those stored for 1 day.

\begin{tabular}{|c|c|c|c|c|c|c|c|c|c|c|c|c|c|c|}
\hline \multirow{2}{*}{ Strength } & \multirow{2}{*}{$\begin{array}{c}\text { COARSE } \\
\text { AGGREGATE }\end{array}$} & \multirow{2}{*}{$\frac{\text { Control }}{\text { C-28 }}$} & \multicolumn{2}{|c|}{$200 \mathrm{AIR}$} & \multicolumn{2}{|c|}{$400 \mathrm{AIR}$} & \multicolumn{2}{|c|}{$600 \mathrm{AIR}$} & \multicolumn{2}{|c|}{200 WATER } & \multicolumn{2}{|c|}{400 WATER } & \multicolumn{2}{|c|}{600 WATER } \\
\hline & & & 200-A-1 & $200-A-28$ & $400-A-1$ & $400-A-28$ & $600-\mathrm{A}-1$ & $600-A-28$ & 200-W-1 & $200-W-28$ & $400-W-1$ & $400-W-28$ & $600-\mathrm{W}-1$ & $600-W-28$ \\
\hline \multirow{4}{*}{ 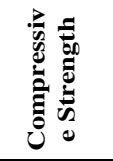 } & Dolomite & 0 & 0 & -3.2 & 0 & -9.9 & 0 & -4.3 & 0 & 1.1 & 0 & 1.4 & 0 & 2.6 \\
\hline & Crushed Concrete & 0 & 0 & -2.7 & 0 & -2.2 & 0 & -4.7 & 0 & 1.9 & 0 & 2.2 & 0 & 1.7 \\
\hline & Crushed Ceramics & 0 & 0 & -1.1 & 0 & -1.6 & 0 & -4.1 & 0 & 1.2 & 0 & 2.5 & 0 & 3.4 \\
\hline & Crushed Red Brick & 0 & 0 & -3.6 & 0 & -6.0 & 0 & -3.3 & 0 & 2.1 & 0 & 2.0 & 0 & 3.6 \\
\hline \multirow{4}{*}{ 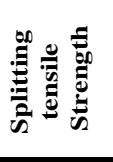 } & Dolomite & 0 & 0 & -3.2 & 0 & -6.1 & 0 & -5.1 & 0 & 1.6 & 0 & 3.0 & 0 & 2.7 \\
\hline & Crushed Concrete & 0 & 0 & -4.1 & 0 & -6.5 & 0 & -4.9 & 0 & 5.5 & 0 & 7.5 & 0 & 5.1 \\
\hline & Crushed Ceramics & 0 & 0 & -1.7 & 0 & -2.1 & 0 & -2.3 & 0 & 1.4 & 0 & 4.6 & 0 & 3.2 \\
\hline & Crushed Red Brick & 0 & 0 & -3.2 & 0 & -6.9 & 0 & -7.5 & 0 & 2.8 & 0 & 4.3 & 0 & 4.5 \\
\hline \multirow{4}{*}{ 范 } & Dolomite & 0 & 0 & -2.1 & 0 & -3.5 & 0 & -7.8 & 0 & 1.8 & 0 & 2.0 & 0 & 2.0 \\
\hline & Crushed Concrete & 0 & 0 & -1.7 & 0 & -2.9 & 0 & -10.5 & 0 & 1.4 & 0 & 4.8 & 0 & 6.7 \\
\hline & Crushed Ceramics & 0 & 0 & -2.5 & 0 & -7.8 & 0 & -4.2 & 0 & 2.1 & 0 & 3.1 & 0 & 3.5 \\
\hline & Crushed Red Brick & 0 & 0 & -1.4 & 0 & -7.4 & 0 & -5.8 & 0 & 1.2 & 0 & 3.2 & 0 & 6.5 \\
\hline \multirow{4}{*}{ 苟 } & Dolomite & 0 & 0 & -3.2 & 0 & -3.4 & 0 & -5.2 & 0 & 0.6 & 0 & 1.6 & 0 & 2.4 \\
\hline & Crushed Concrete & 0 & 0 & -3.2 & 0 & -4.3 & 0 & -7.0 & 0 & 2.3 & 0 & 2.5 & 0 & 3.0 \\
\hline & Crushed Ceramics & 0 & 0 & -2.1 & 0 & -2.3 & 0 & -4.4 & 0 & 2.0 & 0 & 2.0 & 0 & 1.4 \\
\hline & Crushed Red Brick & 0 & 0 & -3.4 & 0 & -2.8 & 0 & -7.1 & 0 & 2.4 & 0 & 4.2 & 0 & 6.5 \\
\hline
\end{tabular}




\section{Conclusions}

In this research, a series of experiments have been performed to investigate the behavior of RA-SC concrete subjected to elevated temperatures ranging between $200^{\circ} \mathrm{C}$ to $600^{\circ} \mathrm{C}$. After exposure to elevated temperature, samples were cooled down by a left at the air or by using water, then stored for 1 or 28 days then tested. Based on the experimental results presented, the following conclusions could be drawn:

1. Using recycled aggregate as coarse aggregates to cast self-curing concrete is efficient, especially when cast using crushed ceramics followed by cast using crushed concrete as an alternative for conventional aggregates, especially for non-structural applications.

2. The behavior of RA-SC under elevated temperature is affected mainly by aggregate type, heating temperature, cooling method and storage time.

3. The loss of strength of RA-SC increases with the increase of elevated temperature up to $69.4 \%$ at $600 \mathrm{oC}$ (in the range of this study).

4. The compressive strength of samples casts using crushed ceramics, crushed concrete, and crushed red bricks decrease by about $5.3 \%, 29.9 \%, 43.9 \%$ compared to that cast using dolomite. They nearly behave in the same manner under splitting tensile, flexure and bond strengths with comparable values.

5. Air-cooling is preferable when dealing with RA-SC concrete at elevated temperatures. Using water cooling affecting badly on concrete strength with a decrease in compressive strength in the range of 1.8$24.8 \%$ compared to those cooled in air.

6. Increasing the storage time after exposure to an elevated temperature, then cooled in the air decreased the compressive strength values with a range of 1.1-9.9\%. When using water cooling, the compressive strength increased by with a range of 1.1$3.6 \%$ of storage time up to 28 days.

Generally, one can use the recycled aggregate self-curing RA-SC concrete under elevated temperatures considering the loss of strength. Using crushed ceramics as a coarse aggregate at elevated temperature is efficient. The use of the RA-SC may consider as an alternative solution to the use of conventionally cured concrete in infrastructures. Firefighting is not recommended by using water due to its bad effects after cooling.

\section{REFERENCES}

[1] EN.1992-1-2.EuroCode.2, "Part 1-2 General RulesStructural Fire Design," Design of Concrete Structures, pp. 211-220, 2004.

[2] S. E. Guise, "Petrographic and Color Analysis for Assessment of Fire Damaged Concrete," in 19th International Conference on Cement Microscopy, 1999.

[3] B. Toumi, M. Resheidat, Z. Guemmadi and H. Chabi, "Coupled Effect of High Temperature and Heating Time on the Residual Strength of Normal and High-Strength Concretes," Jordan Journal of Civil Eng.,2009, Vol. 3, No. 4, Pp. 322-330.

[4] A. A. Bashandy, "Performance of Self-curing Concrete at Elevated Temperatures," Indian Journal of Engineering and Materials Sciences, 2015, Vol. 22, Pp. 93-104.

[5] A. A. Bashandy, "The Influence of Fire and Elevated Temperature on NSC, HSC, and UHSC", Saarbrucken, Deutschland, Germany: LAP LAMBERT Academic Publishing, 2013.

[6] A. A. Bashandy, "Influence of Elevated Temperatures on the Behavior of Economical Reactive Powder Concrete," Journal of Civil Engineering Research, 2013, Vol. 3, No. 3, pp. 89-97.

[7] Y. N. Chan, G. F. Peng and M. Anson, "Residual Strength and Pore Structure of High-strength Concrete and Normal Strength Concrete after Exposure to High Temperatures," Cement and Concrete Composites, 1999, Vol. 21, Pp. 23-27.

[8] L. T. Phan and N. J. Carino, "Mechanical Properties of High Strength Concrete at Elevated Temperatures," National Inst. of Standards and Technology (BFRL), Gaithersburg, MD, 2001.

[9] Z. P. Bazant and M. F. Kaplan, Concrete at High Temperatures: Materials Properties and Mathematical Model, London, England: Longman Press, 1996

[10] O. Arioz, "Effects of Elevated Temperatures on Properties of Concrete," Fire Safety Journal, 2007, Vol. 42, Pp. 516-522.

[11] B. Georgali and P. E. Tsakiridis, "Microstructure of Fire-damaged Concrete: A Case Study," Cement and Concrete Composites, 2005, Vol. 27, No. 2, Pp. 255-259.

[12] G. T. G. Mohamed.bhai, "Effect of Exposure Time and Rates of Heating and Cooling on Residual Strength of Heated Concrete," Magazine of Concrete Research,1986, Vol. 38, No. 136, Pp. 151-158.

[13] M. A. Safan, A. A. Bashandy, M. R. Afify and A. M. AboZed, "Influence of Curing Conditions on The Behavior of Reinforced Self-Curing Slabs Containing Super Absorbent Polymers," in The 9th Alexandria International Conference on Structural and Geotechnical Engineering, Alexandria, 2016

[14] R. K. Dhir, P. C. Hewlett, J. S. Lota and T. D. 
Dyer, "An Investigation into the Feasibility of Formulating 'Self-cure' Concrete," Materials and Structures (Materiaux et Constructions), 1994, Vol. 27, No. 174, Pp. 606-615.

[15] A. A. Bashandy, "Self-curing Concrete under Sulfate Attack," Archives of Civil Engineering, 2016, Vol. 62, No. 2, Pp. 3-18.

[16] A. S. EL-Dieb and S. H. Okba, "Performance of Self Curing Concrete," Ain Shams University, Cairo, Egypt., Cairo, Egypt, 2005.

[17] V. Mangaiarkarasi and S. R. Damodarasamy, "Self-curing Concrete Today's and Tomorrow's Need of Construction World," in International Conference on Recent Advances in Concrete and Construction Technology "INCRAC and CT 2005", Chennai, 2005.

[18] U. S. Rai and R. K. Singh, "Effect of Polyacrylamide on the Different Properties of Cement and Mortar," Materials Science and Engineering: A, 2005, Vol. 392, No. 1, Pp. 4250 .

[19] A. A. Bashandy, N. N. Meleka and M. M. Hamad, "Comparative Study on the Using of PEG and PAM as Curing Agents for Self-Curing Concrete," Challenge Journal of Concrete Research Letters, 2017, Vol. 8, No. 1, Pp. 1-10.

[20] M. Collepardi, A. Borsoi, S. Collepardi, Ogoumah, J. J. Olagot and R. Troli, "Effects of Shrinkage Reducing Admixture in Shrinkage Compensating Concrete Under Non-Wet Curing Conditions," Cement and Concrete Composites, 2005, Vol. 27, No. 6, Pp. 704-708.

[21] M. V. Sandeep, K. R. Kiran and C. H. Anukesh, "A Study on Effect of Curing Compounds on Recycled Aggregate Concrete on Strength and Other Properties," Indian Journal of Science Res.,2018, Vol. 17, No. 2, Pp. 528-535.

[22] Australia, "Use of Recycled Aggregates in Construction," Australia Cement Concrete and Aggregates, Australia, 2008.

[23] A. A. Bashandy and Z. A. Etman, "Recycling of Demolished Building Materials as Concrete Coarse Aggregates in Egypt," in The 8th Alexandria International Conference on Structural and Geotechnical Engineering AICSGE-8, Alexandria, Egypt, 2014.

[24] A. A. Bashandy, N. M. Soliman and M. Hamdy, "Recycled Aggregate Self-curing High-strength Concrete," Civil Engineering Journal "CEJ", 2017, Vol. 3, No. 6, Pp. 427-441.

[25] N. D. Oikonomou, "Recycled Concrete Aggregates," Cement and Concrete Composites, 2005, Vol. 27, No. 2, Pp. 315-318.

[26] J. Rindl, "Recycling Manager," Dane County, , Madison, USA, 1998.

[27] R. R. Nair and R. M. Pannem, "Structural Performance of Recycled Coarse Aggregate Concrete by Different Curing Regimes," International Journal of Civil Engineering and
Technology, vol. 8, pp. 1167-1175, 2017

[28] A. A. Bashandy, M. A. Safan and M. M. Ellyien, "Feasibility of using Recycled-Aggregates in Self-Curing Concrete," in The 9th Alexandria International Conference on Structural and Geotechnical Engineering, Alexandria, 2016

[29] A. A. Bashandy, M. A. Safan and M. M. Ellyien, "Durability of Recycled Aggregate Self-curing Concrete," Journal of Civil Engineering and Architecture, 2017, Vol. 60, No. 2, Pp. 18-38.

[30] J. Bala-Krishna and R. Jaipal, "Comparative and Experimental Study on Self-curing Concrete," International Journal of Research Sciences and Advanced Engineering, 2017, Vol. 2, No. 19, Pp. 118-129.

[31] E.S.S.4756-1/2013, "Portland Cement, Ordinary and Rapid Hardening," Ministry of Industry, Cairo, Egypt, 2009.

[32] E.S.S.1109/2008, "Aggregates for Concrete," Ministry of Industry, Cairo, Egypt, 2008.

[33] ASTM.C-33, "Aggregates," American Society for Testing and Materials ASTM International, Philadelphia, USA, 2003

[34] E.C.P.203/2018, "Egyptian Code of Practice: Design and Construction for Reinforced Concrete Structures," Research Centre for Houses Building and Physical Planning, Cairo, Egypt, 2018

[35] ASTM.C-494, "Chemical Admixtures for Concrete," American Society for Testing and Materials ASTM International, Philadelphia, USA., 2015

[36] E. A. Emam, "Durability of Self-Curing Concrete", Menoufia, Egypt: M. Sc. at Faculty of Engineering, Menoufia University, 2012.

[37] M. I. Nemr, N. M. Soliman, A. A. Bashandy, "Behavior of Recycled Aggregate Self-Curing Concrete at Elevated Temperatures", International Conf. on Innovative Building Materials (IBMC-18), Housing and Building National Research Center "HBRC", Cairo, Egypt, 2018.

[38] K. Singh, "Mechanical properties of self curing concrete studied using polyethylene glycol-400: A-review" materialstodays: proceedings, 2021, Vol. 37, Part 2, Pp. 2864-2871, https://doi.org/10.1016/j.matpr.2020.08.662

[39] N. G. Troncoso, L. Li, Q. Cheng, K. H. Mo \&T. C. Ling, "Comparative study on the properties and high temperature resistance of self-compacting concrete with various types of recycled aggregates"Case Studies in Construction Materials, 2021, Vol. 15, e00678 